\title{
PREVALENCE OF SEROVARS AND ANTIMICROBIAL SUSCEPTIBILITY IN CLINICAL ISOLATES OF Salmonella Spp.
}

\author{
Denada Lacej ${ }^{1,2^{*}}$, Marinela Dibra ${ }^{1}$, Andi Koraqi ${ }^{1,2}$ \\ I"University Hospital Center "Mother Theresa", Laboratory of Clinical Microbiology, Tirana, Albania; \\ ${ }^{2}$ Medical University, Department of Microbiology, Tirana, Albania; \\ *Correspondent author Denada Lace, email: lacejdenada@gmail.com;
}

Received May, 2018; Accepted May, 2018; Published June, 2018;

DOI: https://doi.org/10.31407/ijees8326

UOI license: http://u-o-i.org/1.01/ijees/72242152

\begin{abstract}
The emergence of antibiotic-resistant foodborne pathogens has raised the concern of the public as these pathogens are more virulent, causing an increase in the mortality rate of infected patients The aim of this study was to assess the genotypic diversity associated with antimicrobial susceptibility of Salmonella serovars isolated from patients presenting with diarrhea at University Hospital Centre "Mother Teresa" Tirana over the period 2009-2017. Stool collection, processing and isolation of strains were performed according to the technical working protocol that is applied in laboratory. A total of 290 salmonella strains were isolated over the study period. $4.9 \%$ were Salmonella group B, 5.3\% were Salmonella enterica ss. Arizonae, 8.1\% Salmonella group D, 10.2\% were Salmonella group D1 and $66.3 \%$ were not serotyped and were classified as Salmonella spp. Antimicrobial susceptibility testing showed that $29.4 \%$ of isolates were susceptible to all classes of antibiotics. According to serovars the resistance rate varied from $0-13.9 \%$. 82 isolates were tested for the presence of ESBL. The prevalence of ESBL producing isolates was $48.8 \%$ (95\% CI $37.59-60.09)(40 / 82)$.
\end{abstract}

Key words: prevalence, antibiotic-resistant, pathogens 